OPEN ACCESS

Edited by:

Brigitte Mauch-Mani, Université de Neuchâtel, Switzerland

Reviewed by: Vamsi J. Nalam, Colorado State University, United States Anna-Maria Botha-Oberholster, Stellenbosch University, South Africa

*Correspondence: Li-Hua Zhu Li-Hua.Zhu@slu.se Inger Åhman Inger.Ahman@s/u.se

Specialty section: This article was submitted to Plant Pathogen Interactions,

a section of the journa

Frontiers in Plant Science

Received: 02 March 2020 Accepted: 24 June 2020

Published: 09 July 2020

Citation:

Kim S-Y, Bengtsson T, Olsson N, Hot V, Zhu L-H and Åhman I (2020) Mutations in Two Aphid-Regulated $\beta-1,3-G / u c a n a s e$ Genes by CRISPR/ Cas9 Do Not Increase Barley Resistance to Rhopalosiphum padi L.

Front. Plant Sci. 11:1043. doi: $10.3389 /$ fpls.2020.01043

\section{Mutations in Two Aphid-Regulated $\beta$-1,3-Glucanase Genes by CRISPR/ Cas9 Do Not Increase Barley Resistance to Rhopalosiphum padi L}

\author{
Sung-Yong Kim, Therese Bengtsson, Niklas Olsson, Vehbo Hot, Li-Hua Zhu* \\ and Inger Åhman *
}

Department of Plant Breeding, Swedish University of Agricultural Sciences, Alnarp, Sweden

Callose deposition is induced in plants by various stress factors such as when plants are attacked by herbivores and pathogens. In the case of aphids, callose plugging of aphiddamaged phloem sieve tubes is expected to reduce aphid access to the phloem sap, while aphid-induced upregulation of callose-degrading $\beta$-1,3-glucanase genes in the host plant might counteract this negative effect on aphid performance. We have tested this hypothesis with barley mutants in which one or both of two $\beta$-1,3-glucanase genes (1636 and 1639) have been mutated by CRISPR/Cas9 technique in cv. Golden Promise. These two genes were previously found to be upregulated by the cereal pest Rhopalosiphum padi L. in susceptible barley genotypes. Four 1636/1639 double mutant, three 1636 single mutant and two 1639 single mutant lines were tested for aphid resistance along with control lines. All mutant lines had single base insertions, causing frame shifts and premature stop codons. Three of the four double mutant lines showed significantly reduced $\beta$-1,3-glucanase activity, and bacterial flagellin-induction resulted in significantly more callose formation in the leaves of double mutant compared to control and single mutant lines. However, we found no effect of these modified plant traits on barley resistance to $R$. padi. Both genes were confirmed to be upregulated by $R$. padi in Golden Promise. The gene 1637 is another $\beta$-1,3-glucanase gene known to be upregulated by $R$. padi in barley and was here found to be higher expressed in a double mutant line when compared with a control line. If this can compensate for the general reduction of $\beta$-1,3-glucanase activity in the double mutants is difficult to discern since phloem concentrations of these proteins are unknown.

Keywords: Hordeum vulgare L., $\beta$-1,3-glucanase, CRISPR/Cas9, susceptibility, plant breeding, insect pest

\section{INTRODUCTION}

Aphids are phloem-feeding insects. Out of approximately 4,700 species in the Aphididae family, $c a$ 100 are crop pests (Blackman and Eastop, 2007). They damage plants directly when feeding on phloem sap, but also indirectly by vectoring viral diseases. The most common aphid control method in field crops is to apply insecticides. To grow aphid-resistant cultivars is a control method that is 
more environmentally friendly, less risky for human health, less costly, and more easily applied. However, relatively few cultivars have been bred for resistance to their aphid pests so far. Among the examples are wheat and barley cultivars with resistance to one or both of Schizaphis graminis Rondani and Diuraphis noxia Kurdjumov (Mornhinweg et al., 2012; Tolmay et al., 2015; Mornhinweg et al., 2017), soybean cultivars resistant to Aphis glycines Matsumura (https://extension.umn.edu/soybeanvariety-selection/aphid-resistant-soybean-varieties-minnesota; accessed on 11 November 2019), a lettuce cultivar resistant to Nasonovia ribisnigri (Mosley), and other aphid species (http:// agris.fao.org/agris-search/search.do?recordID=CZ2000000225; accessed on 11 November 2019) and melon cultivars resistant to Aphis gossypii Glover (Boissot et al., 2016).

Plant resistance traits may confer both physiological (antibiosis) and behavioral (antixenosis) effects on the insect (Smith, 1989). Causes for insect resistance are thus more complicated to study than causes for disease resistance. However, compared to chewing herbivorous insects, aphids make only small mechanical damage to their hosts and aphids are relatively sedentary once they have accepted a plant to feed and reproduce on. These are factors that may explain why aphid/host interactions show many similarities with pathogen/host plant interactions. Classical genetic studies or mapping of aphid/plant interactions indicate that dominantly inherited resistance genes, $R$ genes, in several cases take part in the resistance reaction (Dogimont et al., 2010). Two of three aphidresistance genes that have been sequenced so far, $\mathrm{Mi}-1$ in tomato and Vat in melon, belong to the nucleotide-binding-site leucinerich repeat (NBS-LRR) family of $R$ genes (Rossi et al., 1998; Dogimont et al., 2014, respectively). Such genes are involved in plant recognition of certain effectors secreted by pathogens and pests. Early plant responses to the attack include rapid depolarization of the plasma transmembrane potential, a rise in cytosolic $\mathrm{Ca}^{2+}$, production of reactive oxygen species, and mitogenactivated protein kinase signaling. Subsequently, plant hormones interact with transcription factors involved in production of plant secondary metabolites, defense proteins, and other plant defense traits (Erb and Reymond, 2019). For example, when rice expressing the $R$ gene Bhp14 is infested with the phloem feeding planthopper Nilaparvata lugens Stål, the salicylic acid signaling pathway is upregulated, which in turn induces trypsin inhibitor production and callose deposition in phloem causing resistance to the planthopper (Du et al., 2009). However, experience with deployment of cultivars with single $R$ gene resistance is that sooner or later it is overcome by other biotypes/races of the plant antagonist. This has indeed been the case with cereals resistant to the aphids $S$. graminis and $D$. noxia as well as soybean resistant to $A$. glycines and lettuce to N. ribisnigri (Dogimont et al., 2010; Jaouannet et al., 2014).

An alternative strategy to breed for resistance is to reduce plant susceptibility (Pavan et al., 2010; Åhman et al., 2019), rather than to, as in most of the examples mentioned above, introduce $R$ genes. This approach is now facilitated by the novel genome editing method CRISPR/Cas9, which can be used to make a double DNA strand break (DSB) (Shan et al., 2013; Belhaj et al., 2015). The DSB is subsequently repaired by the native non-homologous end joining mechanism (NHEJ), which may erroneously add or delete one or a few nucleotides that may, in turn, result in loss of gene function. There are now several examples where this method has been tested and found useful for breeding disease resistant plants (Weeks et al., 2015; Mushtaq et al., 2019; Sedeek et al., 2019).

To exploit this method in breeding for resistance to aphids it is necessary to first identify candidate genes for susceptibility ( $\AA$ hman et al., 2019). Here we have chosen to study $\beta$-1,3-glucanases which might have a role in reducing clogging of the phloem sieve elements by the $\beta$-1,3-glucan callose. Sieve tubes consist of modified plant cells connected via sieve plates. Phloem sap is transported through callose-lined pores in the sieve plates. Upon mechanical damage to the phloem, these pores are clogged firstly by expanding proteins and somewhat later by callose. These plant reactions are $\mathrm{Ca}^{2+}$-dependent (Van Bel and Will, 2016). However, when aphids puncture the sieve elements there are in most aphid/plant combinations just minor clogging of the sieve plates, allowing the aphid to feed from the same phloem tube for substantial time (Tjallingii, 2006). The reason may be that $\mathrm{Ca}^{2+}$-binding proteins in aphid-exuded saliva reduce build-up of protein and callose plugs (Will et al., 2013). An alternative or complementary explanation is that effectors in aphid saliva induce increased plant production of $\beta$ 1,3 -glucanases that can degrade the $\beta$-glucan callose (Giordanengo et al., 2010; Van Bel and Will, 2016). There are many $\beta$-1,3glucanases with different functions at different stages of plant development, such as during microspore development, pollen germination, pollen tube extension, fruit development, ripening, and seed germination (Balasubramanian et al., 2012; Pirselova and Matusikova, 2013). Certain of the $\beta$-1,3-glucanases belong to the so called pathogenesis-related (PR) proteins (Van Loon and van Strien, 1999; Doxey et al., 2007) induced by pathogens and believed to either target fungal pathogens directly or to elicit other plant defense mechanisms via release of glucan as a damage signal (Balasubramanian et al., 2012). In general, disease resistant plant genotypes show faster accumulation of glucanases than the susceptible ones (Balasubramanian et al., 2012). However, in several studies comparing resistant and susceptible genotypes of aphid-induced plants the relation is the reverse, as determined at the gene expression level. Certain $\beta$-1,3-glucanase transcripts are found to be more abundant in the susceptible than in the resistant genotypes, for example in the interactions between $S$. graminum and sorghum (Park et al., 2006), wheat (Reddy et al., 2013) and switchgrass (Koch et al., 2018), between Acyrthosiphon pisum Harris and barrel medic (Sun et al., 2018a), Sipha flava Forbes. and switchgrass (Koch et al., 2018), and R. padi and barley (Delp et al., 2009; Mehrabi et al., 2016). However, there are also examples where $\beta$-1,3-glucanase transcripts or proteins are more abundant in the resistant genotype (Van der Westhuizen et al., 1998; Forslund et al., 2000; Van der Westhuizen et al., 2002; Botha et al., 2014; Sun et al., 2018b).

In the present study we have developed and characterized barley (Hordeum vulgare L.) mutant lines, in which two $\beta$-1,3glucanase genes (contigs 1636 and 1639) were mutated in the cultivar Golden Promise (GP) using CRISPR/Cas9 technique. These are two of the three glucanase genes commonly found to be upregulated by R. padi in barley germplasm (Delp et al., 2009; 
Saheed et al., 2009; Mehrabi et al., 2016). Our hypothesis is that mutations in one or both of these two genes will hamper the aphid's ability to, indirectly via the host plant, reduce callose deposition in the sieve tubes of barley. The reduced breakdown of callose is in turn anticipated to reduce aphid access to the phloem sap and thereby negatively affect aphid growth and potentially influence aphid host preference as well. This would be a novel way of breeding for resistance to $R$. padi, which is a serious pest of barley in temperate regions worldwide (Blackman and Eastop, 2007).

\section{MATERIALS AND METHODS}

\section{Development and Characterization of Mutant Lines \\ Cloning of the Genes 1636 and 1639}

Two $\beta$-1,3-glucanase genes in GP were PCR-amplified using genomic DNA and CDNA as templates and the primers were designed according to the sequence with accession no X67099 in National Center for Biotechnology Infromation (NCBI) for 1636 and the sequence with accession no AK248899 in NCBI for 1639. The genomic DNA was extracted from young leaf tissues using Thermo Scientific Gene Jet plant genomic DNA purification mini Kit (USA) and RNA using Qiagen RNA extraction Kit (USA) according to the manufacturers' instructions. cDNA synthesis was performed using SuperScript III first-strand synthesis systems according to the manufacturer's instructions (Thermo Fisher, USA). The PCR conditions were $98^{\circ} \mathrm{C}$ for $3 \mathrm{~min}, 30$ cycles of $98^{\circ} \mathrm{C}$ for $10 \mathrm{~s}, 61^{\circ} \mathrm{C}$ for $1 \mathrm{~min}, 72^{\circ} \mathrm{C}$ for $1 \mathrm{~min}$, and final extension of $72^{\circ} \mathrm{C}$ for $10 \mathrm{~min}$. The PCR primers used are shown in Table 1. The PCR products were sequenced by GATC biotech (Germany) and compared with the sequences with the accession numbers mentioned above.

\section{Phylogenetic Analysis of Glucanase Genes and Localization of Glucanases}

Apart from the two genes 1636 and 1639, there is another, 1637 (accession no AJ271367), which was previously shown to be induced by $R$. padi in various barley germplasm (Delp et al., 2009; Saheed et al., 2009; Mehrabi et al., 2016). In order to evaluate how similar the three genes are in GP, and also to compare them with other $\beta$-1,3-glucanase genes in the barley databases, we blasted these three genes against the genome sequence of cv. Morex at IPK's barley blast server (http://webblast.ipk-gatersleben.de/barley_ibsc/) and made a phylogenetic analysis of all the putative $\beta$-1,3-glucanase genes using Phylogeny.fr (maximum likelihood with bootstraps) software. For predicted localization of proteins related to the glucanase genes, the sequences were uploaded to Bologna unified subcellular component annotator (BUSCA; http://busca.biocomp. unibo.it). BUSCA predicts subcellular localization using programs for signal and transit peptides (DeepSig and TPpred3), GPI-anchors (PredGPI), transmembrane domains (ENSEMBLE3.0 and BetAware), and for subcellular localization (BacelLo, MemLoci, and SChloro). Actual isoenzyme information and subcellular protein localization refer to information by Li et al. (1996) and UniProt.org (https://www.uniprot.org/).
TABLE 1 | Primers and sgRNA sequences used in this study.

\begin{tabular}{|c|c|}
\hline Name & Sequence \\
\hline \multicolumn{2}{|c|}{ For cloning of the target genes } \\
\hline 1636-For & 5'-ATGGCGAGGAAAGGTGTAGACGTCGCAGTGGC-3' \\
\hline 1636-Rev & 5'-CTAGAAAGTAATGGCGTAGGCCGGTGACATAT-3' \\
\hline 1639-For & 5'-ATGCAAATACATACGCACCAAGTTATGATAAG-3' \\
\hline 1639-Rev & 5'-TCAGAAAGTAATGGAGTAGGCCGGCGACTTGT-3' \\
\hline \multicolumn{2}{|c|}{ For CRISPR target sequences (sgRNA) of 1636 and 1639 genes } \\
\hline sgRNA-1 & 5'-GTCGGCGTCTGCAACGGCGT-3'a \\
\hline sgRNA-2 & 5'-GTGCGGATCTACGAGCCGGA-3'a \\
\hline sgRNA-3 & 5'-GACTCCATCGGCGTCTGCAA-3'a \\
\hline sgRNA-4 & 5'- GCTCACGGCGCTCAGCGGCA-3'a \\
\hline \multicolumn{2}{|c|}{ For PCR of the target genes for high-resolution fragment analysis (HRFA } \\
\hline 1636 HRFA For & 5'-HEX-ATGGCGAGGAAAGGTGTAG-3' \\
\hline 1636 HRFA Rev & 5'-GAGGAGACGTTGGCCTITAC-3' \\
\hline 1639 HRFA For & 5'-FAM-GATAAGATCGTCGATGGCGAAG-3' \\
\hline 1639 HRFA Rev & 5'-CTTCGCGCCGGGCACCACCGTG-3' \\
\hline \multicolumn{2}{|c|}{ For sequencing of putative mutation lines } \\
\hline 1636-For & 5'-ATGGCGAGGAAAGGTGTAGACGTCGCAGTGGC-3' \\
\hline 1636-Rev & 5'-CTAGAAAGTAATGGCGTAGGCCGGTGACATAT-3' \\
\hline 1639-For & 5'-ATGCAAATACATACGCACCAAGTTATGATAAG-3' \\
\hline 1639-Rev & 5'-ATGGCTGGGAGGATGGT-3’' \\
\hline \multicolumn{2}{|c|}{ For PCR of the hygromycin resistance gene } \\
\hline Hyg-For & 5'-GATGTAGGAGGGCGTGGATA-3' \\
\hline Hyg-Rev & 5'-GATGTTGGCGACCTCGTATT-3' \\
\hline
\end{tabular}

${ }^{a} G$ was added before the target sequences to facilitate the U6 promoter transcription.

\section{CRISPR/Cas9 Vector Construction}

The target sequences of the two $\beta$-1,3-glucanase genes were selected using the CRISPR-design tool CRISPR RGEN (http:// www.rgenome.net). Two CRISPR vectors were constructed where the target sequences were expressed under the monocotoptimized rice U6 promoter. Each target sequence neighboring a 5'-NGG PAM was 19 bp with an additional G inserted to facilitate the U6 promoter-based transcription. Each vector harbors two target sequences and one of them targeted both genes whereas the other was gene specific. The target sequences in vector 1 were sgRNA-1 for targeting both genes and sgRNA-2 for targeting 1636, and in vector 2 were sgRNA-3 for targeting both genes and sgRNA-4 for targeting 1639 (Table 1).

Preparation of the CRISPR vectors and plant transformation were carried out at John Innes Centre (JIC), UK, as described by Lawrenson and Harwood (2019) and Hinchliffe and Harwood (2019).

\section{Growth Conditions in the Biotron}

The transgenic rooted plantlets from JIC were transferred from in vitro to soil in $1.5 \mathrm{~L}$ pots and grown in a growth chamber in the biotron at SLU, Alnarp. To accelerate the subsequent generation cycles, speed breeding conditions were adopted (Watson et al., 2018), namely $20 \mathrm{~h}$ photoperiod at $22^{\circ} \mathrm{C}$ and $4 \mathrm{~h}$ dark at $20^{\circ} \mathrm{C}$ and small pot size. Relative humidity was $80 \%$ and photosynthetically active radiation (PAR) was $500 \mu \mathrm{mol} \mathrm{m} \mathrm{s}^{-2}$ at plant level using metal-halogen lamps.

\section{Identification and Characterization of Mutant Lines}

Genomic DNA was extracted from lyophilized and grinded young leaves. $500 \mu \mathrm{l}$ lysis buffer (0,1 M Tris- $\mathrm{HCl}, 20 \mathrm{mM}$ EDTA, 1,4 M $\mathrm{NaCl}$, and $2 \% \mathrm{CTAB}, \mathrm{pH} 7,5)$ was added and samples were 
incubated at $52^{\circ} \mathrm{C}$ for $15 \mathrm{~min}$. Following centrifugation at $2,000 \mathrm{~g}$ for $15 \mathrm{~min}, 200 \mu \mathrm{l}$ supernatant was transferred to Qiacube HT for DNA extraction using the QIAamp 96 DNA QIAcube HT Kit (Qiagen, Hilden, Germany). The DNA was used for PCR and subsequent high-resolution fragment analysis (HRFA) (Andersson et al., 2017) using the capillary electrophoresis-instrument Genetic Analyser 3500 (Thermo Fisher Scientific, Waltham, USA). In HRFA the size of a fluorescently labeled PCR product of a putative mutant was compared with an internal standard and the wild type PCR product. Gene-specific primers were designed with a fluorescent dye (SigmaAldrich, St. Louis, USA) attached to the 5'-end of the forward primers (Table 1). PCR was performed in a reaction containing $1 \mathrm{X}$ Phusion HF buffer, $0,2 \mathrm{mM}$ dNTPs, $0,25 \mu \mathrm{M}$ of each primer, 0,2 units of Phusion polymerase, $1 \mu \mathrm{LNA}$ extract, and water up to $10 \mu \mathrm{l}$ (Thermo Fisher Scientific, Waltham, USA). The PCR conditions were $98^{\circ} \mathrm{C}$ for $3 \mathrm{~min}, 35 \mathrm{cycles}$ of $98^{\circ} \mathrm{C}$ for $10 \mathrm{~s}, 61^{\circ} \mathrm{C}$ for $10 \mathrm{~s}, 72^{\circ} \mathrm{C}$ for $20 \mathrm{~s}$, and final extension of $72^{\circ} \mathrm{C}$ for $10 \mathrm{~min}$. For sequencing, PCR products amplified with the non-labeled primers under the same PCR conditions were ligated into the pJET1.2/blunt vector, which was then transformed into $E$. coli. DH5 $\alpha$. The plasmid DNA was isolated using plasmid extraction kit from Thermo Fisher (USA). The primers were the same as for gene cloning except for the reverse primer for 1639 (Table 1). The PCR products were sequenced by GATC biotech (Germany). PCR of the hygromycin resistance gene was performed to screen for transgene-free plants using primers yielding a product of $450 \mathrm{bp}$ analyzed by electrophoresis using $1.2 \%$ agarose gel (Table 1). PCR conditions were $98^{\circ} \mathrm{C}$ for $3 \mathrm{~min}$, 30 cycles of $98^{\circ} \mathrm{C}$ for $10 \mathrm{~s}, 61^{\circ} \mathrm{C}$ for $1 \mathrm{~min}, 72^{\circ} \mathrm{C}$ for $1 \mathrm{~min}$, and final extension of $72^{\circ} \mathrm{C}$ for $10 \mathrm{~min}$.

\section{$\beta-1,3-$ Glucanase Activity}

The $\beta$-1,3-glucanase activity in the seedlings of the mutant lines along with the controls (see result section for the detailed information about the plant materials and number of replicates used) was assessed based on the dinitrosalicylic acid (DNS) method (Miller, 1959) using laminarin as a substrate (Sigma L9634, USA). Proteins were extracted from the green parts of two weeks old seedlings. The seedlings were frozen in liquid nitrogen and ground with mortar and pestle in the protein extraction buffer from Agrisera (Sweden), supplemented with proteinase inhibitors (Roche, USA). Protein amount was quantified using the BCA protein assay kit from Thermo Fisher, USA. The protein extract $(100 \mu \mathrm{l})$ was mixed with $100 \mu \mathrm{l}$ of $2 \%$ (w/v) laminarin and incubated at $37^{\circ} \mathrm{C}$ for $1 \mathrm{~h}$. The reaction was terminated by adding $1 \mathrm{ml}$ of $1 \%(\mathrm{v} / \mathrm{v})$ staining DNS and boiling for $5 \mathrm{~min}$. After cooling down at room temperature, the solution was diluted 1:20 in distilled water and the absorbance at $500 \mathrm{~nm}$ was measured by spectrophotometer. The $\beta$-1,3-glucanase activity was estimated as nmol of released reducing sugar (D-glucose) per hour per milligram of soluble protein.

\section{Callose Visualization and Quantification}

The second leaffrom two weeks old seedlings was cut into $1 \mathrm{~cm}$ long pieces and then incubated with $1 \mu \mathrm{M}$ Flg22 in $150 \mathrm{mM} \mathrm{K}_{2} \mathrm{HPO}_{4}$ buffer for $24 \mathrm{~h}$ at room temperature. Flg22 is a callose-inducing peptide derived from bacterial flagellin (Gomez-Gomez et al., 1999). Meanwhile, untreated leaf pieces were also incubated in the buffer.
After treatment, the leaves were de-stained in 1:3 acetic acid/ethanol until transparency. After washing in $150 \mathrm{mM} \mathrm{K}_{2} \mathrm{HPO}_{4}$ for $30 \mathrm{~min}$, the leaves were incubated with $0.01 \%$ aniline blue in $150 \mathrm{mM}$ $\mathrm{K}_{2} \mathrm{HPO}_{4}$ solution for $2 \mathrm{~h}$ in dark. Thereafter, the leaves were preserved in $50 \%$ glycerol. Callose depositions were observed at $370 / 509 \mathrm{~nm}$ (aniline blue excitation/emission wave lengths) using a fluorescence microscope with DAPI filter (Leica DMLB, Germany). Amount of callose was quantified from the digital photos of Flg22treated leaves as number of bright pixels using the Adobe software Photoshop's “Record measurement” tool (cf. Luna et al., 2011).

\section{Aphid Tests}

\section{Aphid Rearing in the Greenhouse}

Rearing was started with winged $R$. padi collected from the winter host Prunus padus L. in Saxtorp in 2018 and in Alnarp in 2019. The aphids were reared on oats (Avena sativa L.) in cages in a greenhouse chamber kept at minimum $18^{\circ} \mathrm{C}$ and minimum $16 \mathrm{~h}$ light, natural light supplemented by $400 \mathrm{~W}$ HQIE lamps.

\section{Barley Plants for Aphid Tests}

For all aphid tests, seeds were soaked in water on filter paper in a refrigerator $\left(4-8^{0} \mathrm{C}\right)$ for $3 \mathrm{~d}$, thereafter germinated in the laboratory for $2 \mathrm{~d}$. The seedlings were planted in Emmaljunga exklusiv Blom \& Plantjord soil (Emmaljunga torvmull AB, Vittsjö, Sweden) in $10 \mathrm{~cm}$-diameter plastic pots, placed for testing in greenhouse or biotron chambers. Young plants were used for aphid tests since $R$. padi performs best during seedling to stem elongation of barley (Leather \& Dixon, 1981).

\section{Aphid Regulation of $\beta-1,3-$ Glucanase Gene Expression}

The expression levels of the two genes 1636 and 1639 were analyzed in GP by qRT-PCR to evaluate the aphid effects on gene expression (Figure 1A). Barley plants were grown in a climatecontrolled growth chamber in the biotron, illuminated with PAR $200 \mu \mathrm{mol} \mathrm{m} \mathrm{s}^{-2}$ at plant level using metal-halogen lamps $16 \mathrm{~h}$ per day, at a temperature of $20^{\circ} \mathrm{C}$ and relative humidity $80 \%$. The experiment was started $15 \mathrm{~d}$ after planting, in which 20 aphids were caged on the mid-section of the second leaf in the same type of cage as was used for the test of aphid individual growth after preinfestation (see below). There were five replicates per treatment, each one including two plants from which the caged sections of the leaves were pooled. The treatments included control 1 (without cage) with leaf samples taken at time 0 , control 2 (with cage) after 6 and $24 \mathrm{~h}$ and aphid-infested after 6 and $24 \mathrm{~h}$. The leaf samples were immediately frozen in liquid nitrogen and stored at $-80^{\circ} \mathrm{C}$ for further use.

In order to test if the 1637 gene expression was differently induced in a double mutant in comparison to a non-mutated genotype segregated from the same transformation event, the induction experiment was also carried out with a 1636/1639 double mutant line and a control line, but the sampling was at 0 and $24 \mathrm{~h}$ only and with four replicates per treatment.

\section{RNA Extraction and cDNA Synthesis}

The frozen leaf samples were homogenized in a Retsch Mixer Mill MM400 (Retsch GmbH, Haan, Germany) for $1 \mathrm{~min}$ at $30 \mathrm{~Hz}$. Total 


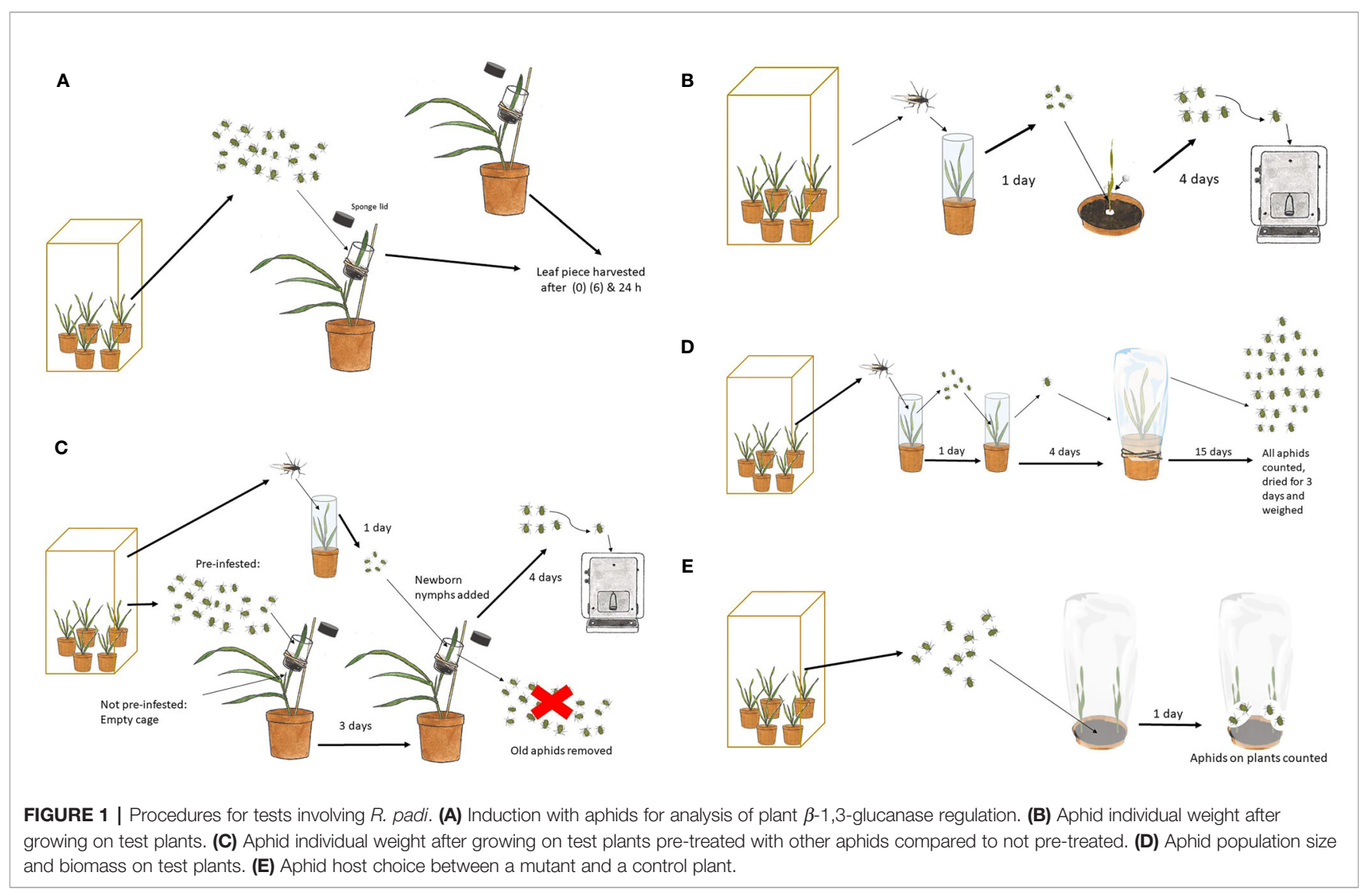

RNA was extracted using the RNeasy Mini Kit (Qiagen GmbH, Hilden, Germany) and the remaining genomic DNA was removed using RNase-free DNase I (Qiagen) following manufacturers' instructions. RNA concentration and purity $(260 / 280 \mathrm{~nm}>1.8)$ were checked using a ND-1000 NanoDrop (Wilmington, USA), and the integrity was analyzed by gel electrophoresis using E$\mathrm{Gel}^{\circledR} 1.2 \%$ (Life Technologies, Carlsbad, CA). The DNA-free RNA $(0.6 \mu \mathrm{g})$ was then reverse-transcribed to cDNA using Superscript III reverse transcriptase enzyme (Life Technologies).

\section{RT-qPCR Analysis}

RT-qPCR was performed using a CFX96 Touch $^{\text {TM }}$ Real-Time PCR Detection System (Bio-Rad Laboratories, Inc., Hercules, CA, USA) for all three $\beta$-1,3-glucanase genes. In addition, two reference genes, $20 \mathrm{~S}$ proteasome alpha subunit $\mathrm{E}$ (SF427) and heat shock protein $(\mathrm{H} v \mathrm{H} s \mathrm{p} 70)$ were included for normalization. The PCR protocol and primer sequences were the same as previously published by Mehrabi et al. (2016). The data normalization was performed according to the method described by Vandesompele et al. (2002).

\section{Aphid Individual Growth}

These tests (Figure 1B) were performed with seedlings under the same controlled conditions as described above for plant propagation in the biotron. Two days after planting, a Perspex cylinder $(5 \mathrm{~cm}$ long and $2 \mathrm{~cm}$ in diameter) was slipped over each seedling allowing the plant to grow through. Eight days after planting, five new-born nymphs were placed in the cylinder cage at the base of each plant and the top of the cage was sealed with cotton wool. The nymphs had been born on oats by winged females collected in the rearing cages the day before. After $4 \mathrm{~d}$ of growth, the nymphs were weighed individually on a Mettler M3 micro balance. Each plant genotype was replicated four times with one plant for each replicate.

\section{Aphid Individual Growth After Pre-Infestation}

This test (Figure 1C) was performed in the greenhouse chamber, under the same conditions as for aphid rearing described above. After planting, each pot was covered with a perforated plastic bag to hinder premature aphid infection. Eleven or $12 \mathrm{~d}$ after planting, a plastic cylinder cage $(4.5 \mathrm{~cm}$ long and $2.5 \mathrm{~cm}$ diameter $)$ was placed around the mid-section of the youngest fully developed leaf and kept in place by sponges with a slit for the leaf at the bottom and top of the cage. The cage was attached with a rubber band to a flower stick for support. Twenty aphids at different developmental stages were released in each cage in the pre-infestation treatment with the intention to try to accentuate callose induction. The cages in the non-infested treatment were left without aphids. After $3 \mathrm{~d}$, all the aphids were removed with a soft brush and five newborn nymphs were released in each cage of both pre-infested and noninfested plants. From here on, the experiment was performed as in the aphid individual growth experiment. Each line and treatment was represented by six plants. 


\section{Aphid Population Growth}

This test (Figure 1D) was performed in the greenhouse chamber under the conditions described above for aphid rearing. The experiment started with winged females released on oat seedlings in a $10 \mathrm{~cm}$-diameter pot covered with a Perspex cylinder $(19.5 \mathrm{~cm}$ tall and $6.5 \mathrm{~cm}$ in diameter). The day after, newborn nymphs were transferred to new oat seedlings in the same type of cylinder cage. Four days later, nymphs, now close to adulthood, were transferred singly to mutated and control barley plants, which had been grown for 12 or $13 \mathrm{~d}$ after planting. Each genotype was replicated 10 times with one plant and founder female for each replicate. The plants were covered with a perforated plastic bag $(80 \times 36 \mathrm{~cm}$; Cryovac SM57OY, Baumann Saatzuchtbedarf GMBH, Germany) from planting and onwards, to avoid premature aphid infestation, and to keep the test aphid and its offspring on the test plant. The number of aphids per plant was counted $15 \mathrm{~d}$ after female release and the weight of the whole aphid population was recorded after drying at $30^{\circ} \mathrm{C}$ for $3 \mathrm{~d}$.

\section{Aphid Host Choice}

This test (Figure 1E) was performed in the greenhouse chamber under the same conditions as described above for aphid rearing. In a $10 \mathrm{~cm}$-diameter pot, one control and one mutant seedling were planted, opposite to each other, $1 \mathrm{~cm}$ from the pot wall. Since aphids commonly move toward the light before locating a nearby plant to feed on, every second pot in a row was turned $180^{\circ}$ in relation to the previous one. The pot was covered with a perforated plastic bag to hinder premature aphid infestation and to keep the test aphids confined. One week after planting, 10 apterous adults or nymphs close to adulthood were released on the soil in the middle of the pot. The test included four double mutant lines along with the control plants. Each mutant and control combination was represented by 16 pots, namely 16 replicates. One day later, the released aphids were counted, excluding nymphs that had been born on the plants.

\section{Statistical Analyses}

ANOVAs were performed using the software STATISTICA v. 9.1. For details of the ANOVAs see Tables, Figures and Supplementary Table S1.

\section{RESULTS}

\section{Sequences of the 1636 and 1639 Genes in GP}

The 1636 gene has one intron while 1639 has no intron in GP, as previously shown for barley cv. Morex. The cDNA of 1636 shows 98.7\% homology with the coding sequence of the glucanase gene with accession no. X67099 and 1639 shows $98.2 \%$ homology with the coding sequence of the glucanase gene with accession no. AK248899.

\section{Phylogenetic Relationships of Putative $\beta$-1,3-Glucanase Genes and Localization of the Glucanases in Barley}

The phylogenetic analysis of all putative $\beta$-1,3-glucanase genes in the genome sequence of Morex showed 21 putative $\beta-1,3-$ glucanase genes, clustering in three main groups. The genes
1636,1639 , and 1637 all belong to the same main gene clade, but the 1636 and 1639 sequences are most similar (Figure 2). All three are expected to produce proteins that are excreted extracellularly, like most of the other $\beta$-1,3-glucanases (Figure 2; Li et al., 1996; Roulin et al., 1997).

\section{Gene Expression Levels With and Without Aphid Infestation}

In order to confirm the expression levels of the target genes in GP to be used for mutagenesis, we performed qRT-PCR analyses of the genes 1636 and 1639 with or without aphid infestation. Both transcripts showed significant upregulation upon aphid infestation for $24 \mathrm{~h}$ (Figure 3). In order to test if the 1637 gene expression was different in a mutant homozygous for 1636 and 1639 mutations compared to a non-mutated genotype, the induction experiment was also carried out with a double mutant in comparison with a control line (see line production below). The mutant line had a significantly higher expression of 1637 than the control line, without as well as with the aphid treatment. There was a tendency of, but not a significant upregulation of 1637 by $R$. padi in both genotypes (Figure 4). We interpret the increase of all three transcripts with time in the treatments without aphids to be a plant reaction to the cages applied to the leaves.

\section{Molecular Characteristics of Mutants}

We obtained 76 plantlets $\left(\mathrm{T}_{0}\right)$ from JIC, which had been confirmed transgenic by PCR analysis for the hygromycin resistance gene. Mutations in the transgenic lines of GP were first screened by HRFA whereby DNA base insertions or deletions in the target regions could be identified, down to one base pair (bp) indel (Andersson et al., 2017). Twenty one of the $76 \mathrm{~T}_{0}$ plants showed mutations in the target genes, of which, 20 showed mutation in one of the two target genes, while one showed mutations in both genes. Offspring produced by selfing $(S)$ of several mutant $T_{0}$ lines were further screened for mutations in the target genes by HRFA, followed by sequencing in the subsequent generations to bring plants to homozygosity. Meanwhile, the segregation also resulted in lines that do not have any mutations in the target genes, and such lines were used as controls in the study. All confirmed mutant lines used in subsequent plant characterizations and aphid tests had $1 \mathrm{bp}$ insertion, which had occurred only in the target sequences common to both genes and for both vectors (Figure 5). Furthermore, all lines used in the aphid tests were CRISPR/Cas9-vector free as determined by PCR analysis for the hygromycin resistance gene in the transformation vectors.

Hereafter, we refer to lines as single 1636, single 1639, or double mutants. Designations for lines are as follows: the first digit represents transformation vector 1 or 2 . The second digit denotes the original transgenic plant no. (tissue-cultured plant $\mathrm{T}_{0}$ ). The third digit denotes the no. of an $\mathrm{S}_{1}$ plant obtained from selfing of $\mathrm{T}_{0} . \mathrm{S}_{1}$ plants were further selfed, for one (fourth digit) or two (fifth digit) generations to obtain homozygous lines for further analyses.

Four double mutant (1-16-3-1, 1-37-8-2, 1-37-24-1, and 2-29-4$3-5)$, three 1636 single mutant (1-37-33-4, 1-37-35-1 and 1-21-33$1)$, and two 1639 single mutant (1-37-40-1 and 1-18-34-1) lines were characterized further. All these mutants had a single base 


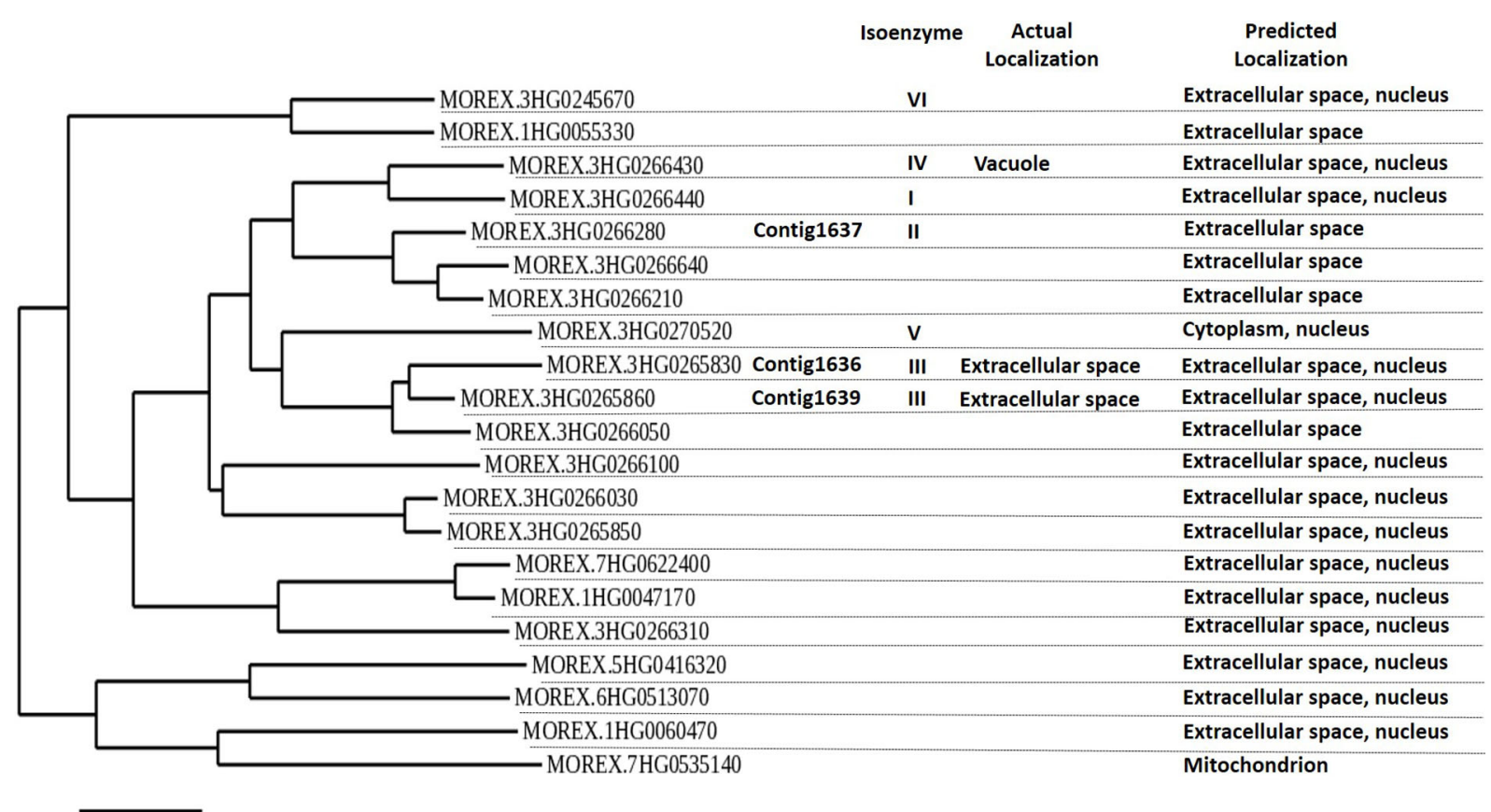

FIGURE 2 | Phylogenetic tree of putative barley $\beta$-1,3-glucanase genes based on barley cultivar Morex DNA sequence, using Phylogeny.fr (maximum likelihood with bootstraps) software. $\beta$-1,3-Glucanase contigs 1636, 1637, and 1639 are indicated. $\beta-1,3$-Glucanase Morex sequences were obtained on December 2019 after blasting 1636, 1637, and 1639 in IPK's barley blast server (http://webblast.ipk-gatersleben.de/barley_ibsc/). Actual isoenzyme information and subcellular protein localization refer to information by Li et al. (1996) and UniProt.org. Predicted localization of expression is from Bologna unified subcellular component annotator (BUSCA) (http://busca.biocomp.unibo.it).

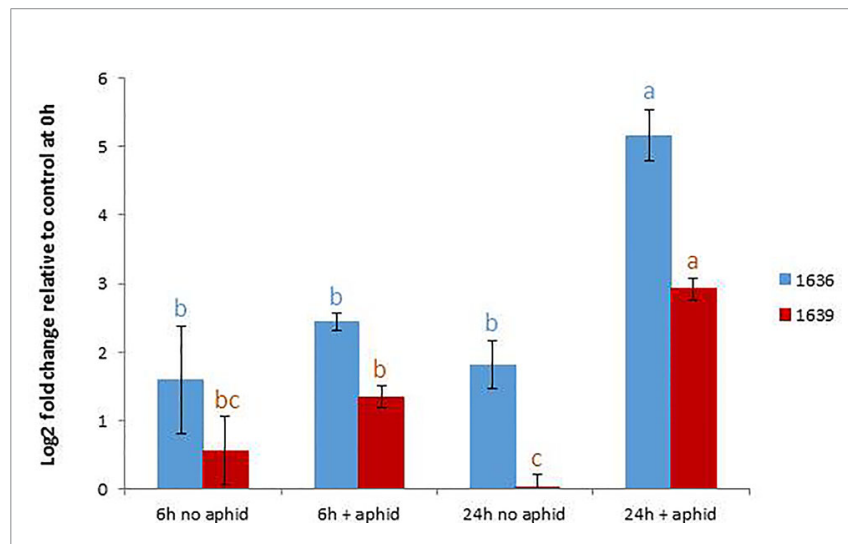

FIGURE 3 | Relative gene expression levels (mean \pm SE, $n=5$ ) of 1636 and 1639 in Golden Promise, expressed as fold change relative to their expressions at the start of the experiment and normalized against the changes in expression level of the reference genes SF427 and Hsp70. The data were analyzed by one-way ANOVA (see Table S1), followed by Tukey's multiple comparison test for each gene separately. Different letters above bars indicate significant differences at $p=0.05$.

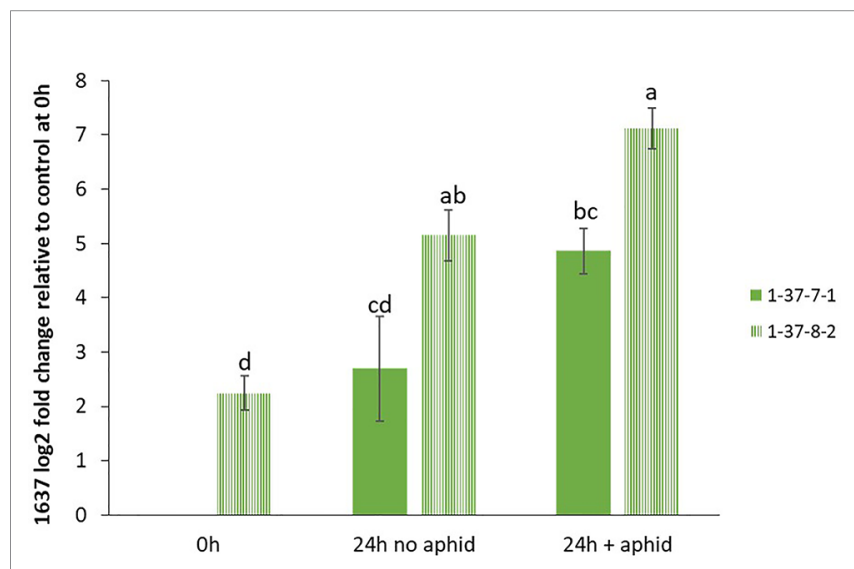

FIGURE 4 | Relative gene expression levels (mean $\pm \mathrm{SE}, \mathrm{n}=4$ ) of $\beta$-1,3glucanase gene 1637, expressed as fold change relative to its expression in the control line 1-37-7-1 at the start of the experiment and normalized against changes in expression level of the reference genes SF427 and Hsp70. The data were analyzed by one-way ANOVA (see Table S1), followed by Tukey's multiple comparison test. Different letters above bars indicate significant differences between the double mutant line 1-37-8-2 and control line 1-37-71 or between different treatments at $p=0.05$. 


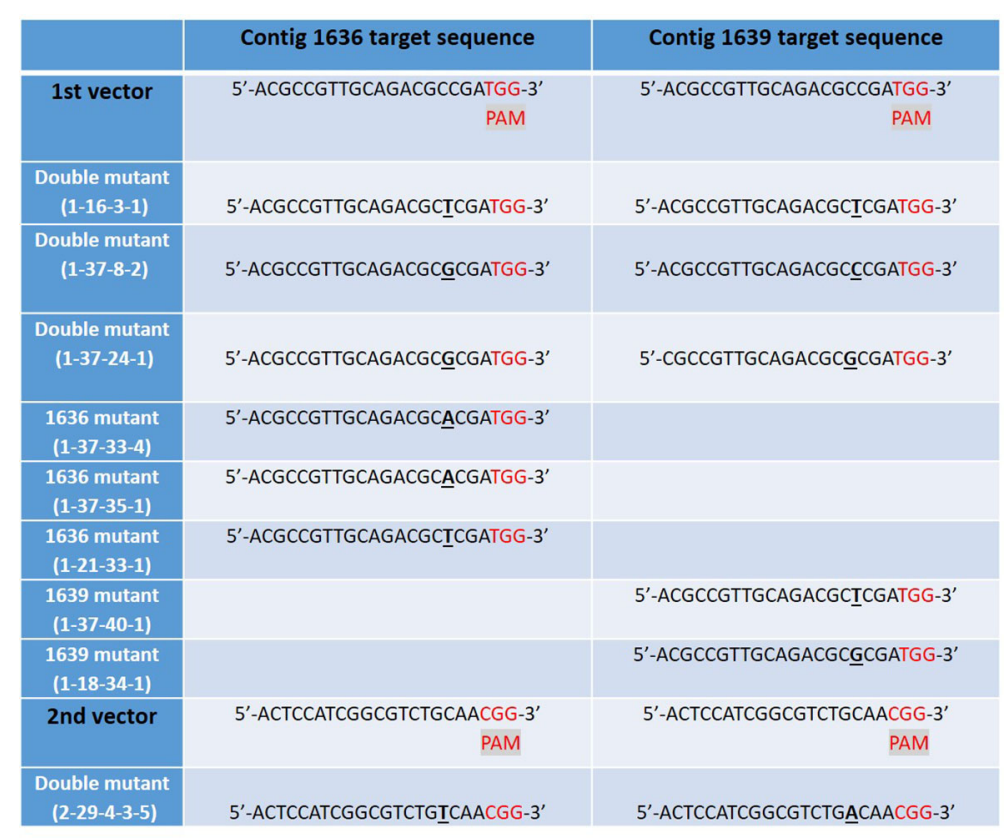

FIGURE 5 | The mutated CRISPR/Cas9 target sites of $\beta$-1,3-glucanase gene sequences in nine studied lines of barley cv Golden Promise, derived from five different transgenic plants: 1-16, 1-37, 1-21, 1-18, and 2-29. Single DNA base inserts are shown in underlined bold text and a protospacer adjacent motif (PAM) site in red. Two different vectors were used to generate the mutant lines, each targeting the two $\beta$-1,3-glucanase genes 1636 and 1639 resulting in lines with one or both target genes mutated.

insertion (Figure 5) resulting in a frame shift causing a premature stop codon that might lead to a non-functional protein. All but one of the mutants had a stop codon at the same site (Figure 6). The 229-4-3-5 double mutant had it much earlier in the DNA sequence of the 1639 gene, expected to result in a protein 121 amino acids shorter than the others' (Figure 6).

\section{$\beta-1,3-$ Glucanase Enzymatic Activity in Mutant Lines}

Total $\beta$-1,3-glucanase enzymatic activity was measured in an assay using laminarin as substrate. Three out of four double mutant lines had significantly lower $\beta$-1,3-glucanase activity than the two controls, up to $40 \%$ lower, whereas the single mutants did not differ in enzymatic activity compared to that of the controls (Figure 7).

\section{Callose in Mutant Lines}

Leaves of double mutant plants treated with flagellin had significantly more callose than the plants of 1636 or 1639 single mutant or control lines (Figure $\mathbf{8 K}$ ). Also non-treated plants of double mutants tended to have more callose than plants of the other two categories (Figures 8A-J).

Double and single mutants did not show any morphological differences compared to control lines.

\section{Aphid Responses Aphid Individual Growth}

Single or double mutant lines from five different transformation events representing both vectors were tested for how well they supported aphid growth, experiments with lines from $\mathrm{T}_{0}$ 1-18 and 1-16 replicated over generations and lines from $\mathrm{T}_{0} 2-29$ replicated three times. Reduced growth is an indicator of plant resistance. No significant differences were found between the control and mutant lines with regards to individual weight of aphids after $4 \mathrm{~d}$ of nymphal growth on the test plants (Table 2).

\section{Aphid Individual Growth After Pre-Infestation}

Single 1636, single 1639 , and double mutant lines from the $\mathrm{T}_{0}$ no. 1-37 were compared with control lines that had segregated out as non-mutated. There was no significant difference in individual nymphal weight between plants with and without aphid infestation prior to the 4-d long aphid growth test (Table 3). Moreover, there was no significant difference in individual aphid weight between mutant and control lines in this test either.

\section{Aphid Population Growth}

The same lines that were tested for individual aphid growth after pre-infestation were also tested for aphid population growth after release of one founder female per test plant. There was no significant difference in aphid population size or aphid biomass weight between any of the lines after $15 \mathrm{~d}$ of aphid reproduction (Table 4).

\section{Aphid Host Choice}

Pairs of control and double mutant lines from three different $\mathrm{T}_{0}$ were compared with regards to aphid host choice one day after infestation. Reduced aphid acceptance of a plant is another type of indicator for plant resistance. In one of the comparisons aphids were significantly more abundant on the mutant than on 
A

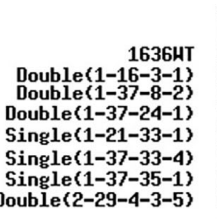

1636 HT

Double (1-16-3-1) Double(1-37-24-1) Single(1-21-33-1) Single $(1-37-33-4)$ Double (2-29-4-3-5)

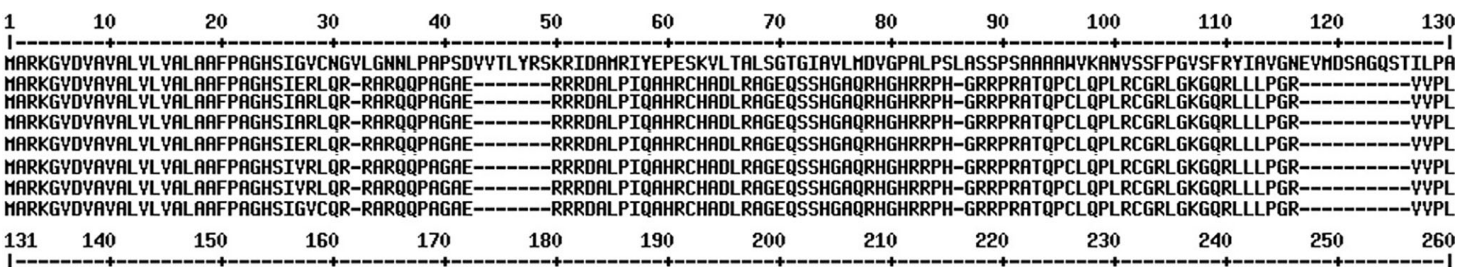

I

HRRRORGHGQRRPEYHPPGHEERATGARGRRPRRHQGY--HYGAYRRLQQHFPTLQRCFGGQYRYPEFHP STOP

HRRRQRGHGQRRPEYHPPGHEERATGARGRRPRRHQGY--HYGAYRRLOOHFPTLQRCFGGQVRUPEAHP STOP

HRRRQRGHGQRRPEYHPPGHEERATGARGRRPRRHQGY--HYGAYRRLQQHFPTLQRCFGGQYRUPEAHP STOP

HRRRQRGHGQRRPEYHPPGHEERATGARGRRPRHQGY--HYGAYRRLQQHFPTLQRCFGGQYRYPEAHP STOP

HRRRQRGHGQRRPEYHPPGHEERATGARGRRPRRHQGY--HYGAYRRLQQHFPILQRCFGGQYRYPEFHP STOP

HRRRQRGHGQRRPEYHPPGHEERATGRRGRRPRRHQGY--HYGAYRRLQQHFPTLQRCFGGQYRUPEAHP STOP

HRRRQRGHGQRRPEYHPPGHEERATGRRGRRPRRHQGY--HYGAYRRLQQHFPTLQRCFGGQYRYPEAHP STOP

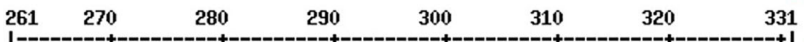

16364t SDQGFGATAQNARAYNQGLINHYGNGTPKKAGALETYIFAMFNENLKDGDELEKNFGLFKPNMSPAYAITF STOP

Double (1-16-3-1)

Double (1-37-8-2)

Double $(1-37-24-1)$

Single (1-21-33-1)

Single (1-37-33-4)

Single (1-37-35-1)

Double (2-29-4-3-5)

B

16394T

Double(1-16-3-1-1

Double(1-37-8-2)

Double (1-37-24-1)

Single (1-18-34-1)

Single $(1-37-40-1)$
Double $(2-29-4-3-5)$

Double (2-29-4-3-5)

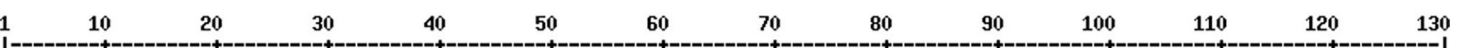
MQIHTPQYMIRSSMAKQGYAPMLAYALYAIYALAFFPAYHSIGYCNGYIADNLPAPSDYYKLYQSKGIKAMRIYAPESNYLKALSGTGIGLLMDYGNGALSGLANDPSARPAHYKANIQPYPGYSFRYIA MQIHTPQYHIRSSHAKQGYAPYLAYAL YAIYALAFFPAYHSIERLQ---RRDRGQPAGTERRREALPIQGHQSHADLRAGEQRPQGGQRHGHRPAHGRRQRRAIRPRQRPLRRARLGQGQHPALPGRYLP HQIHTPQYMIRSSMAKQGUAPYL AYALVAIYAL AAFPAYHSIERLQ---RRDRGQPAGTERRREALPIQGHQSHADLRAGEQRPQGAQRHGHRPAHGRRQRRAIRPRQRPLRRARLGQGQHPALPGRULP MQIHTPQYHIRSSHAKQGYAPYLL AYL YATYALAAFPAYHSIGRLQ---RRDRGQPAGTERRREALPIQGHQSHADLRAGEQRPQGAQRHGHRPAHGRRQRRAIRPRQRPLRRARLGQGQHPALPGRYLP MQIHTPQYHIRSSHAKQGYAPHLAYALYAIYALAFFPAYHSIARLQ---RRDRGQPAGTERRREALPIQGHQSHADLRAGEQRPQGAQRHGHRPAHGRRQRRAIRPRQRPLRRARLGQGQHPALPGRVLP MQIHTPQYHIRSSHAKQGYAPHLAYALYAIYALAFFPAYHSIERLQ---RRDRGQPAGTERRREALPIQGHQSHADLRAGEQRPQGAQRHGHRPAHGRRQRRAIRPRQRPLRRARLGQGQHPALPGRYLP
MQIHTPQYHIRSSHAKQGYAPMLAYALYAIYALAFFPAYHSIGYSTOP

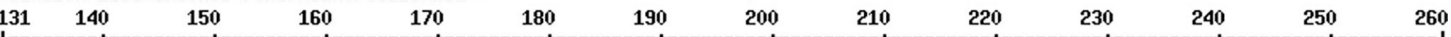

1639нт YGNEYMDSAGOKTILPAMKNHKKALYDAGLSGGYKYSTSYRFDYYTDTFPPSNGYFADLDYHGPILDFLASTGAPLLANYYPYFAYKGDPQNIKLNYATFFPGTTYNDDGNGLTYTHLFDAMYDSIYAPL Double (1-16-3-1-1) LHRRRQRGHGQRR--PEDHPPSHEEHEKGFRGRRP STOP

Double (1-37-8-2) LHRRRQRGHGQRR--PEDHPPSHEEHEKGARGRRP STOP

Single(1-18-34-1) LHRRRQRGHGQRR--PEDHPPSHEEHEKGARGRRP STOP

Single (1-37-40-1) LHRRRQRGHGQRR--PEDHPPSHEEHEKGARGRRP STOP

Double(2-29-4-3-5)

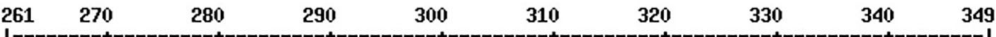

1639HT EDANMPGYKLYYSESGHPSASGFGATRONHOAYNOGLINHYGNGTPKRPGALETYIFAMFNENOKDGEETEKNFGLFKPDKSPAYSITFSTOP

Double(1-16-3-1-1)

Double $(1-37-8-2)$

Double(1-37-8-2)

Single $(1-18-34-1)$

Single $(1-37-40-1)$

Double(2-29-4-3-5)

FIGURE 6 | Predicted proteins from the 1636 (A) and 1639 (B) mutant lines. Translation of genes from cultivar Morex wild type (WT) is compared with translations of the nine mutant lines.

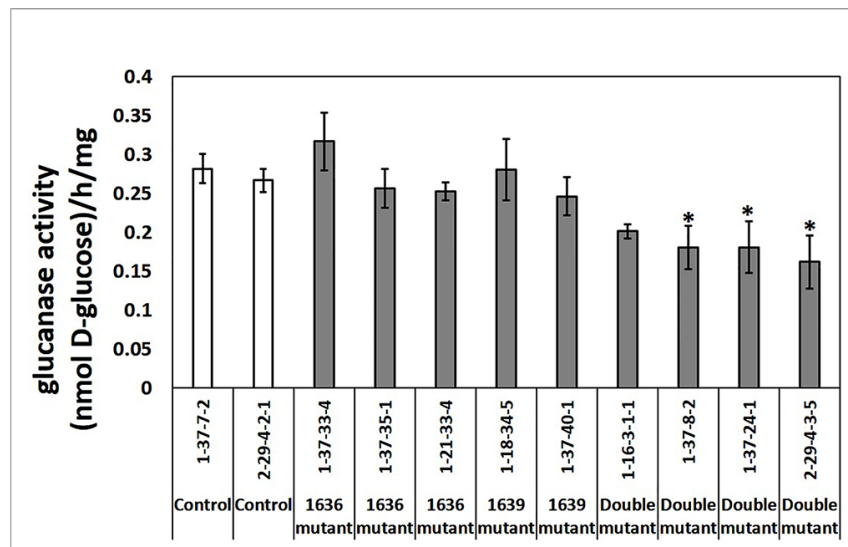

FIGURE 7 | Total $\beta$-1,3-glucanase activities (mean \pm SE, $\mathrm{n}=4$ or 5 ) in crude protein extracts of seedlings from two control lines, five single and four double mutant barley lines. The data was analyzed by one-way ANOVA (see Table S1), followed by LSD test at $p=0.05$. * above the bar indicate significant differences between the mutant line and both control lines. the control line but when retested there was no significant preference (Table 5).

\section{DISCUSSION}

In the present study there was no support for our expectation that performance of $R$. padi would be hampered by mutations in two of the three glucanase genes previously found to be upregulated by this aphid in various barley germplasm (Delp et al., 2009; Saheed et al., 2009; Mehrabi et al., 2016), and here also found upregulated in the GP cultivar. This was first tested in the populations derived from five different CRISPR/Cas9 transformation events of GP representing four different single base insertions in 1636 and 1639, respectively, using a standard test for aphid individual growth. This particular test method has previously been used for resistance screening in a barley breeding program and has been confirmed to successfully select for $R$. padi resistance, as determined by reduced population growth in a field 


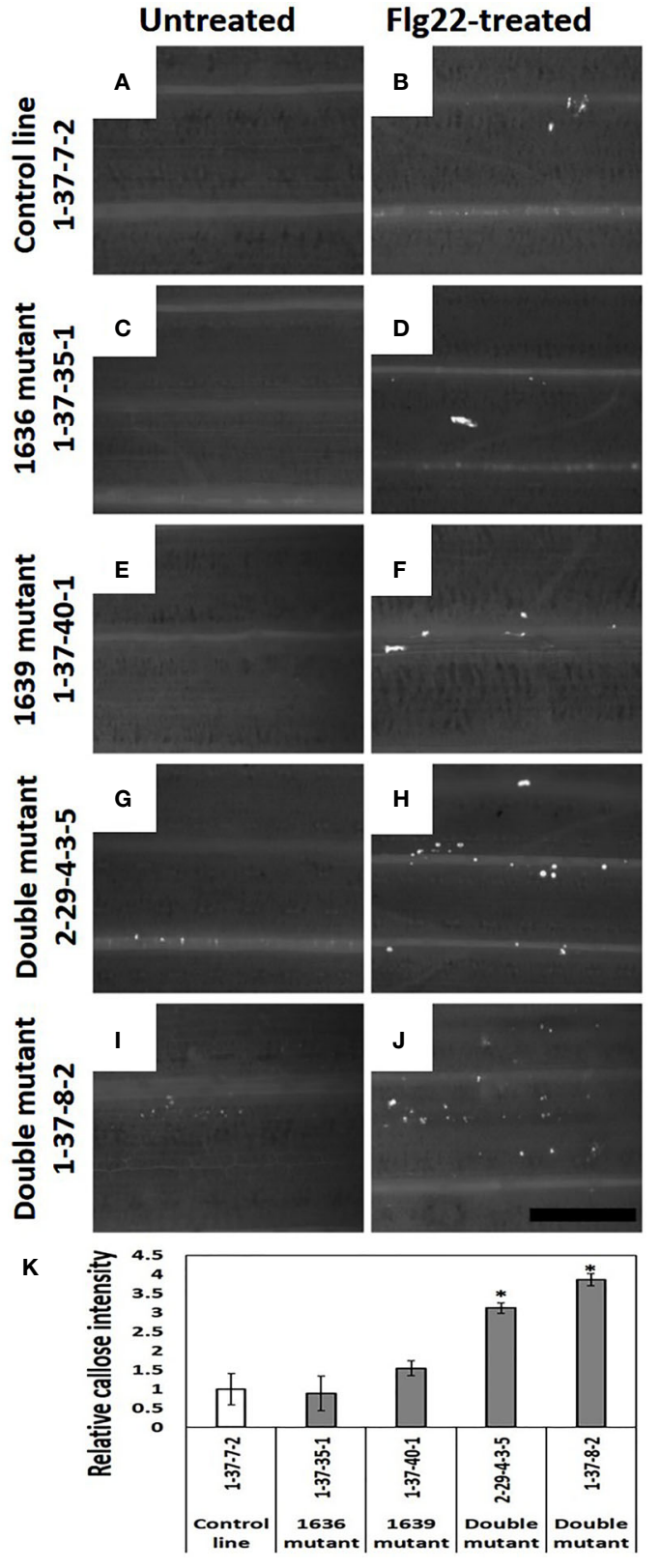

FIGURE 8 | Callose deposition (white spots in the images) in barley leaves of 2 weeks old seedlings, without (A, C, E, G, I) and with Flg22 treatment (B, D, $\mathbf{F}, \mathbf{H}, \mathbf{J})$. Callose was stained with aniline blue. $a$ and $b=$ control line 1-37-7-2, $\mathrm{c}$ and $\mathrm{d}=1636$ mutant line 1-37-35-1, e and $\mathrm{f}=1639$ mutant line 1-37-40-1, $\mathrm{g}$ and $\mathrm{h}=$ double mutant line 2-29-4-3-5, and $\mathrm{i}$ and $\mathrm{j}=$ double mutant line 1-37-82. Scale bar $500 \mu \mathrm{m}$. (K) Number of pixels corresponding to the color of callose in Flg22-treated leaves of mutant lines relative to that of a control line (mean $\pm \mathrm{SE}, \mathrm{n}=4$ ). The data was analyzed by one-way ANOVA (see Table S1), followed by LSD test at $p=0.05$. * above the bar indicate significant differences between the mutant and the control line.

test as well as by molecular markers for the resistance (Åhman and Bengtsson, 2019). However, since this test lasted only for $4 \mathrm{~d}$ and included just five young aphids per cage and plant, we repeated it but with addition of a pre-infestation treatment of the plants with 20 aphids that were removed after $3 \mathrm{~d}$ when the actual test was started with newborn nymphs. The rationale for this was that the high aphid density at pre-infestation was expected to induce so much callose in the phloem vessels that the plants mutated in one or two $\beta$-1,3-glucanase genes would not be able to degrade it to the extent that normal plants do, which in turn would reduce phloem sap access and aphid growth. However, this pre-infestation did not affect the result as no significant effect on aphid growth was found when comparing the single or double mutant lines with the controls from the same family. The same lines were also subjected to an $R$. padi population growth test, which lasted for $15 \mathrm{~d}$, but again no significant differences between mutant and control lines were found. Finally, we performed a choice test to investigate if $R$. padi was able to detect the effects of these mutations. Here again no significant difference in aphid preference was found between the mutant and control lines except for one combination, which showed that the aphids preferred the mutant. However, since this result could not be reproduced, it might be a statistical Type I error.

Plant analyses showed that total $\beta$-1,3-glucanase enzymatic activity was significantly reduced in three of the four double mutant lines tested. Presence of callose in leaves tended to be more predominant constitutively in the double mutant lines compared to single mutant and control lines. This was further accentuated when the plants were provoked with the Flg22 peptide from bacterial flagellin, a protein known to trigger callose deposition (Gomez-Gomez et al., 1999). However, as described above, this increased callose deposition in the double mutant lines did not affect the $R$. padi performance and host preference.

There are many $\beta$-1,3-glucanase genes in barley. Saheed et al. (2009) identified 16 unigenes for $\beta$-1,3-glucanases for barley in the NCBI database and Li et al. (1996) showed seven genes for $\beta$-1,3glucanase isoenzymes to be located on the long arm of chromosome $3 \mathrm{H}$. In our study, through blasting the DNA sequences of 1636, 1637, and 1639 against the genome sequence of $\mathrm{cv}$. Morex, we distinguished 21 putative $\beta$-1,3-glucanase genes, some of which clustering closely with the three genes. 1636 and 1639 align with genes coding for proteins belonging to the isoenzyme group GIII and 1637 with a gene coding for a protein in isoenzyme group GII. GII and GIII isoenzymes are basic proteins, which are secreted extracellularly (Li et al., 1996; Roulin et al., 1997). Various barley pathogens such as Blumeria graminis (Jutidamrongphan et al.,1991; Ignatius et al., 1994), Bipolaris sorokiniana (Jutidamrongphan et al., 1991), and Rhynchosporium secalis (Roulin et al., 1997) have been shown to upregulate GII and GIII isoenzyme genes and the promoter of GIII isoenzyme genes is activated by the plant defense hormone salicylic acid (Li et al., 2005).

The reason why we concentrated on the three $\beta$-1,3-glucanase genes 1636,1639 , and 1637 was that they have been shown to be upregulated by $R$. padi in previous studies even if the expression levels of the three genes differed depending on barley genotype and the methods used for analyses. In a microarray study, Delp et al. 
TABLE 2 | Rhopalosiphum padi individual weight (mean $\pm \mathrm{SE}, \mathrm{n}=4$ ) after $4 \mathrm{~d}$ of growth on test plants.

\begin{tabular}{|c|c|c|c|c|c|c|c|}
\hline Plant type & Line no. (generation $\mathrm{S}_{2}$ ) & Aphid weight $(\mu \mathrm{g})$ & p-value & Plant type & Line no. (generation $\mathrm{S}_{3}$ or $\mathrm{S}_{4}$ ) & Aphid weight $(\mu g)$ & p-value \\
\hline & & & & Control $^{a}$ & $1-37-7-1$ & $270 \pm 19$ & 0.19 \\
\hline & & & & Control & $1-37-7-2$ & $315 \pm 28$ & \\
\hline & & & & Double mutant & $1-37-8-2$ & $329 \pm 31$ & \\
\hline & & & & Double mutant & $1-37-24-1$ & $260 \pm 27$ & \\
\hline & & & & Mutant 1636 & $1-37-33-4$ & $330 \pm 46$ & \\
\hline \multirow[t]{8}{*}{ Mutant 1636} & $1-37-35$ & & & & & $250 \pm 21$ & \\
\hline & & & & Mutant 1639 & $1-37-40-1$ & $293 \pm 33$ & \\
\hline & & & & Control & $2-29-4-2-1$ & $302 \pm 24$ & 0.14 \\
\hline & & & & Double mutant & $2-29-4-3-5$ & $251 \pm 13$ & \\
\hline & & & & Control & $2-29-4-2-1$ & $363 \pm 45$ & 0.18 \\
\hline & & & & Double mutant & $2-29-4-3-5$ & $307 \pm 40$ & \\
\hline & & & & Control $^{b}$ & $2-29-4-2-1$ & $263 \pm 18$ & 0.28 \\
\hline & & & & Double ${ }^{b}$ mutant & $2-29-4-3-5$ & $302 \pm 18$ & \\
\hline Control & $1-18-46$ & $414 \pm 78$ & 0.14 & Control & $1-18-46-1$ & $264 \pm 39$ & 0.29 \\
\hline \multirow[t]{3}{*}{ Mutant 1639} & $1-18-34$ & $508 \pm 35$ & & Control & $1-18-46-2$ & $341 \pm 68$ & \\
\hline & & & & Mutant 1639 & $1-18-34-1$ & $251 \pm 44$ & \\
\hline & & & & Mutant 1639 & $1-18-34-3$ & $257 \pm 16$ & \\
\hline Control & $1-21-31$ & $541 \pm 48$ & 0.31 & & & & \\
\hline Mutant 1636 & $1-21-33$ & $463 \pm 35$ & & & & & \\
\hline Control & Mean $^{c}$ & $436 \pm 40$ & 0.08 & Control & Mean $^{c}$ & $298 \pm 22$ & 0.29 \\
\hline \multirow[t]{2}{*}{ Double mutant } & $1-16-3$ & $402 \pm 36$ & & Double mutant & $1-16-3-1$ & $236 \pm 28$ & \\
\hline & & & & Double mutant & $1-16-3-2$ & $249 \pm 46$ & \\
\hline
\end{tabular}

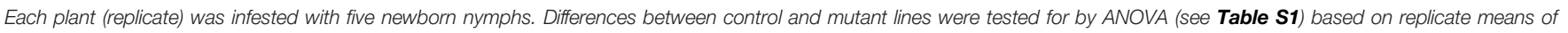
individual aphid weights.

${ }^{a}$ Control lines originated from the same $T_{0}$ from which mutation lines were segregated, except for $T_{0}$ 1-16 where no such control line was obtained.

${ }^{b}$ Aphids of Alnarp origin. All the other tests were made with aphids originating from Saxtorp.

${ }^{c}$ Means for other controls (from $T_{0}$ origins 1-18 and 1-21 or 1-18 and 1-37 tested simultaneously) were calculated per replicate and used in statistics for the mutants from $T_{0}$ 1-16.

TABLE 3 | Rhopalosiphum padi individual weight (mean $\pm \mathrm{SE}, \mathrm{n}=6$ ) after $4 \mathrm{~d}$ of growth on the test plants that had been either pre-infested with 20 aphids (all aphids removed after $3 \mathrm{~d}$ ) or without pre-infestation.

\begin{tabular}{lccc}
\hline Plant type $^{\mathbf{a}}$ & Line no. & $\begin{array}{c}\text { Aphid weight }(\boldsymbol{\mu g}) \\
\text { Pre-infested }\end{array}$ & $\begin{array}{c}\text { Aphid weight }(\boldsymbol{\mu g}) \\
\text { Not pre-infested }\end{array}$ \\
\hline Control $^{\mathrm{b}}$ & $1-37-7-1$ & $239 \pm 17$ & $241 \pm 17$ \\
Control & $1-37-7-2$ & $215 \pm 14$ & $219 \pm 11$ \\
Double mutant & $1-37-8-2$ & $237 \pm 19$ & $226 \pm 18$ \\
Double mutant & $1-37-24-1$ & $223 \pm 7$ & $266 \pm 12$ \\
Mutant 1636 & $1-37-33-4$ & $227 \pm 24$ & $210 \pm 11$ \\
Mutant 1639 & $1-37-40-1$ & $239 \pm 20$ & $236 \pm 20$ \\
\hline
\end{tabular}

Each plant (replicate) was infested with five newborn nymphs. There were no significant aphid weight differences among the lines $(p=0.36)$ or between the pre-infestation treatments $(p=0.75)$ when tested by ANOVA (see Table S1) based on replicate means of individual aphid weights.

a Lines were tested in generation $S_{3}$.

${ }^{b}$ Control lines originated from the same $T_{0}$ plant 1-37 from which mutations were segregated.

(2009) found 1636 to be more upregulated in two susceptible than in two partially resistant cultivars, while 1637 was upregulated in all four. The gene 1639 and another gene were expressed constitutively in the susceptible lines and two other genes were expressed constitutively in the resistant lines. Mehrabi et al. (2016) found 1639 and 1637 to be more upregulated in the susceptible breeding lines in all comparisons where there were significant differences between susceptible and resistant lines. In total, 15 lines were analyzed and all of them expressed genes 1639 and 1637 and aphids significantly upregulated 1639 in 13 of the lines and 1637 in seven of the lines. The gene 1636 was expressed in only five of the 14 successfully analyzed lines with upregulation in four lines
(Mehrabi et al., 2016). Saheed et al. (2009) analyzed 12 out of 16 glucanase genes in the aphid-susceptible cv. Clipper and found 1636 and 1637 to be upregulated by R. padi and 1639 constitutively expressed along with two other genes (whereas all five were strongly upregulated by the aphid $D$. noxia). From this spectrum of barley glucanase gene responses to $R$. padi there is reason to believe that the glucanase coded for by the gene 1637 might also play a role in aphid resistance. In GP with mutations both in 1636 and 1639, 1637 was higher expressed than in the control line, something which might potentially compensate for reduced expressions of 1636 and 1639.

At present it is unknown if there are certain $\beta$-1,3-glucanases in barley that are predominantly localized to sieve elements, a localization which would be most relevant for influencing aphid performance. Since sieve element cells lack nuclei, glucanases in phloem must be produced in adjacent cells (Van Bel and Will, 2016). Glucanases from all three genes studied here are known to be localized extracellularly, but one might speculate as to whether 1637 , and not 1636 and 1639 , has such phloem specificity and if this might explain the absence of effects from the double mutants on $R$. padi resistance. Regarding tissue specificity of callose synthases, Glucan Synthase-Like7 (GSL7) in Arabidopsis has been shown to be responsible for callose deposition in sieve pores (Barratt et al., 2011; Xie et al., 2011).

The extent of callose deposition as a plant response to aphid infestation differs depending on aphid and plant species, as well as aphid and plant genotype. Aphid/plant combinations where callose deposition is more extensive are $D$. noxia infesting barley (Saheed et al., 2009) and wheat (Van der Westhuizen et al., 1998; Van der Westhuizen et al., 2002), M. persicae infesting resistant 
TABLE 4 | Aphid population size (mean \pm SE) 15 d after release of one female $R$. padi per plant.

\begin{tabular}{|c|c|c|c|c|c|c|}
\hline Plant type $^{a}$ & Line no. & No. replicates & No. of aphids & p-value & Dry weight of aphid colony (mg) & p-value \\
\hline Control $^{\mathrm{b}}$ & $1-37-7-1$ & 7 & $299 \pm 44$ & 0.11 & $32.2 \pm 4.6$ & 0.07 \\
\hline Control & $1-37-7-2$ & 10 & $275 \pm 47$ & & $28.3 \pm 5.5$ & \\
\hline Double mutant & $1-37-8-2$ & 10 & $393 \pm 35$ & & $42.1 \pm 3.1$ & \\
\hline Double mutant & $1-37-24-1$ & 9 & $271 \pm 48$ & & $26.1 \pm 5.5$ & \\
\hline Mutant 1636 & $1-37-33-4$ & 8 & $404 \pm 44$ & & $42.0 \pm 4.5$ & \\
\hline Mutant 1639 & $1-37-40-1$ & 9 & $307 \pm 61$ & & $29.5 \pm 5.7$ & \\
\hline
\end{tabular}

There were initially 10 plants (replicates), but this number was reduced due to death of the founder female in four of the six lines. There were no significant differences in mean number of aphids or mean aphid biomass when tested by ANOVA (see Table S1).

a $L$ ines were tested in generation $\mathrm{S}_{3}$

${ }^{b}$ Control lines originated from the same $T_{0}$ plant from which mutations were segregated.

TABLE 5 | Number of aphids (Mean \pm SE, $n=16$ ) on a mutant and a control plant grown in the same pot.

\begin{tabular}{lcc}
\hline $\begin{array}{l}\text { No. of aphids } \\
\text { Control }^{\text {ab }}\end{array}$ & Double mutant & $\begin{array}{c}\text { Paired t-test } \\
\text {-value } \boldsymbol{p} \text {-value }\end{array}$ \\
\hline $1-37-7-1$ & $1-37-8-2$ & \\
$2.1 \pm 0.4$ & $4.0 \pm 0.4$ & 3.000 .01 \\
$3.4 \pm 0.4$ & $3.6 \pm 0.4$ & 0.200 .84 \\
$1-37-7-1$ & $1-37-24-1$ & \\
$2.8 \pm 0.4$ & $3.4 \pm 0.5$ & 0.840 .41 \\
$1-37-7-1$ & $1-16-1-1-1$ & \\
$2.8 \pm 0.3$ & $2.2 \pm 0.3$ & 1.250 .23 \\
$2-29-4-2-1$ & $2-29-4-3-5$ & 0.390 .71 \\
$2.8 \pm 0.4$ & $2.5 \pm 0.4$ & \\
\hline
\end{tabular}

Counts were made $24 \mathrm{~h}$ after release of 10 apterous adults, or nymphs close to adulthood. ${ }^{a}$ Control lines originated from the same $T_{0}$ plant from which mutations were segregated, except for test of mutant line 1-16-1-1-1.

${ }^{b}$ Lines were tested in generations $\mathrm{S}_{3}$ or $\mathrm{S}_{4}$.

Capsicum baccatum (Sun et al., 2018b), and Macrosiphum euphorbiae Thomas in potato, although in this latter case callose accumulation was less in the apoplast and phloem sieve tubes where the aphids resided than in distal plant parts (Samaha, 2017). This is in line with our hypothesis, that aphids reduce callose locally, potentially via induced upregulation of plant $\beta$-1,3-glucanases. An Arabidopsis mutant study suggests that callose deposition is a resistance factor and that especially one of the $\beta$-1,3-glucanases studied play a role in plant susceptibility to $M$. persicae (Shoala et al., 2018). There are also examples of interactions between secondary metabolites and callose build-up. Activation of the defense compounds DIMBOA-glucoside in maize (Ahmad et al., 2011) and a methylated indolyl glucosinolate in Arabidopsis (Clay et al., 2009) triggers callose deposition which in the maize case correlates with resistance to the aphid Rhopalosiphum maidis (Fitch) (Meihls et al., 2013). R. padi infestation causes less callose deposition than $D$. noxia on the same susceptible barley host, but in none of the cases was this found to be due to regulation of the callose synthesis genes by the aphids. Neither was it a result of stronger $\beta$ 1,3-glucanase gene upregulation by $R$. padi than by $D$. noxia, but rather to the difference in callose synthase activation by the two aphids (Saheed et al., 2009). Will and Vilcinskas (2015) suggest that the predominant protein in aphid gelling saliva and the resulting hardened stylet sheet prevent sieve-tube occlusion which would otherwise result from calcium influx from the apoplast into the aphid-damaged sieve element. However, stylet sheet formation is typical for all aphids, including $D$. noxia. This suggests that the callose-inducing signal in the D. noxia interaction with barley is phloem-transported (Saheed et al., 2009). The localization of $\beta$-1,3glucanases as a result of $D$. noxia infestation was concentrated to cell walls of the vascular bundles but more so in resistant than in susceptible plants (Van der Westhuizen et al., 2002).

Callose deposition in plants is induced by various stress factors such as mechanical wounding, high temperature, certain chemicals and infestation by plant pathogens, including viruses. Similar to our hypothesis, pathogen induction of plant $\beta$ 1,3-glucanases might counteract this callose defense. However, Zavaliev et al. (2013) found that only the constitutively expressed $\beta$-1,3-glucanase localized to plasmodesmata, and not the virusinduced type, influenced tobamovirus cell to cell movement in Arabidopsis.

Through mutations in two of the three $\beta$-1,3-glucanase genes, commonly found to be upregulated by $R$. padi in barley susceptible to this aphid, we were unable to confirm the hypothesis that these proteins function as major aphid susceptibility factors. However, to completely reject this hypothesis it is necessary to also study barley mutants in which the third $\beta$-1,3-glucanase gene has been knocked out. Moreover, deeper knowledge about the cellular localization of the $\beta$-1,3-glucanase gene expressions and protein depositions would help further interpretation of our results.

\section{DATA AVAILABILITY STATEMENT}

The raw data supporting the conclusions of this article will be made available by the authors, without undue reservation, to any qualified researcher.

\section{AUTHOR CONTRIBUTIONS}

IÅ suggested the hypothesis and led the project together with L-HZ. $\mathrm{S}$-YK propagated, analyzed and described the plant material molecularly and biochemically, with the exception of RT-qPCR analyses of the target genes performed by TB and HRFA analyses performed by NO. IÅ planned and VH performed the aphid tests. 
IÅ and S-YK wrote the main part of the manuscript. NO and TB wrote their parts and L-HZ contributed improvements to the whole manuscript.

\section{ACKNOWLEDGMENTS}

Mark Smedley and Wendy Harwood at John Innes Centre are cordially thanked for designing the vectors and producing the $\mathrm{T}_{0}$ plants. Annelie Augustinsson is thanked for illustrating the aphid

\section{REFERENCES}

Ahmad, S., Veyrat, N., Gordon-Weeks, R., Zhang, Y., Martin, J., Smart, L., et al. (2011). Benzoxazinoid metabolites regulate innate immunity against aphids and fungi in maize. Plant Physiol. 157, 317-327. doi: 10.1104/pp.111.180224

Åhman, I., and Bengtsson, T. (2019). Introgression of resistance to Rhopalosiphum padi L. from wild barley into cultivated barley facilitated by doubled haploid and molecular marker techniques. Theor. Appl. Gen. 132, 1397-1408. doi: 10.1007/s00122-019-03287-3

Åhman, I., Kim, S.-Y., and Zhu, L.-Z. (2019). Plant genes benefitting aphids potential for exploitation in resistance breeding. Front. Plant Sci. 10, 1452. doi: $10.3389 /$ fpls.2019.01452

Andersson, M., Turesson, H., Nicolia, A., Fält, A.-S., Samuelsson, M., and Hofvander, P. (2017). Efficient targeted multiallelic mutagenesis in tetraploid potato (Solanum tuberosum) by transient CRISPR-Cas9 expression in protoplasts. Plant Cell Rep. 36, 117-128. doi: 10.1007/s00299-016-2062-3

Balasubramanian, V., Vashisht, D., Cletus, J., and Sakthivel, N. (2012). Plant $\beta-1,3-$ glucanases: their biological functions and transgenic expression against phytopathogenic fungi. Biotechnol. Lett. 34, 1983-1990. doi: 10.1007/s10529012-1012-6

Barratt, D. H. P., Koelling, K., Graf, A., Pike, M., Calder, G., Findlay, K., et al. (2011). Callose synthase GSL7 is necessary for normal phloem transport and inflorescence growth in Arabidopsis. Plant Physiol. 155, 328-341. doi: 10.1104/pp.110.166330

Belhaj, K., Chaparro-Garcia, A., Kamoun, S., Patron, N. J., and Nekrasov, V. (2015). Editing plant genomes with CRISPR/Cas9. Curr. Opin. Biotechn. 32, 76-84. doi: 10.1016/j.copbio.2014.11.007

Blackman, R. L., and Eastop, V. F. (2007). "Taxonomic issues," in Aphids as Crop Pests. Eds. H. F. van Emden and R. Harrington (Trowbridge, UK: CABI), 1-29. doi: 10.1079/9780851998190.0001

Boissot, N., Schoeny, A., and Vanlerberghe-Masutti, F. (2016). Vat, an amazing gene conferring resistance to aphids and viruses they carry: From molecular structure to field effects. Front. Plant Sci. 7, 1420. doi: 10.3389/fpls.2016.01420

Botha, A.-M., van Eck, L., Burger, N. F. V., and Swanevelder, Z. H. (2014). Nearisogenic lines of Triticum aestivum with distinct modes of resistance exhibit dissimilar transcriptional regulation during Diuraphis noxia feeding. Biol. Open 3, 1116-1126. doi: 10.1242/bio.201410280

Clay, N. K., Adio, A. M., Denoux, C., Jander, G., and Ausubel, F. M. (2009). Glucosinolate metabolites required for an Arabidopsis innate immune response. Science 323, 95-101. doi: 10.1126/science. 1164627

Delp, G., Gradin, T., Åhman, I., and Jonsson, L. M. V. (2009). Microarray analysis of the interaction between the aphid Rhopalosiphum padi and host plants reveals both differences and similarities between susceptible and partially resistant barley lines. Mol. Genet. Genomics 281, 233-248. doi: 10.1007/ s00438-008-0409-3

Dogimont, C., Bendahmane, A., Chovelon, V., and Boissot, N. (2010). Host plant resistance to aphids in cultivated crops: Genetic and molecular bases, and interactions with aphid populations. Comptes Rendus Biol. 333, 566-573. doi: 10.1016/j.crvi.2010.04.003

Dogimont, C., Chovelon, V., Pauquet, J., Boualem, A., and Bendahmane, A. (2014). The Vat locus encodes for a CC-NBS-LRR protein that confers resistance to Aphis gossypii infestation and A. gossypii-mediated virus resistance. Plant J. 80, 993-1004. doi: 10.1111/tpj.12690

Doxey, A. C., Yaish, M. W. F., Moffatt, B. A., Griffith, M., and McConkey, B. J. (2007). Functional divergence in the Arabidopsis $\beta$-1,3-glucanase gene family test methods (Figure 1). The Swedish Research Council FORMAS provided financial support via the grant 220-2014-1330.

\section{SUPPLEMENTARY MATERIAL}

The Supplementary Material for this article can be found online at: https:/www.frontiersin.org/articles/10.3389/fpls.2020.01043/ full\#supplementary-material

inferred by phylogenetic reconstruction of expression states. Mol. Biol. Evol. 24 , 1045-1055. doi: 10.1093/molbev/msm024

Du, B., Zhang, W., Liu, B., Hu, J., Wei, Z., Shi, Z., et al. (2009). Identification and characterization of $B h p 14$, a gene conferring resistance to brown planthopper in rice. PNAS 106, 22163-22168. doi: 10.1073/pnas.0912139106

Erb, M., and Reymond, P. (2019). Molecular interactions between plants and insect herbivores. Annu. Rev. Plant Biol. 70, 527-557. doi: 10.1146/annurevarplant-050718-095910

Forslund, K., Pettersson, J., Bryngelsson, T., and Jonsson, L. (2000). Aphid infestation induces PR-proteins differently in barley susceptible or resistant to the birdcherry-oat aphid (Rhopalosiphum padi). Physiol. Plant. 110, 496502. doi: 10.1111/j.1399-3054.2000.1100411.x

Giordanengo, P., Brunissen, L., Rusterucci, C., Vincent, C., van Bel, A., Dinant, S., et al. (2010). Compatible plant-aphid interactions: How aphids manipulate plant responses. Comptes Rendus Biol. 333, 516-523. doi: 10.1016/j.crvi.2010.03.007

Gomez-Gomez, L., Felix, G., and Boller, T. (1999). A single locus determines sensitivity to bacterial flagellin in Arabidopsis thaliana. Plant J. 18, 277-284. doi: 10.1046/j.1365-313X.1999.0045.x

Hinchliffe, A., and Harwood, W. A. (2019). "Agrobacterium-mediated transformation of barley immature embryos," in Barley: Methods and protocols, Methods in molecular biology, vol. 1900. Ed. W. A. Harwood (New York, USA: Humana Press), 115-126. doi: 10.1007/978-1-4939-8944-7_8

Ignatius, S. M. J., Chopra, R. K., and Muthukrishnan, S. (1994). Effects of fungal infection and wounding on the expression of chitinases and $\beta$-1,3-glucanases in near-isogenic lines of barley. Physiol. Plant. 90, 584-592. doi: 10.1034/ j.1399-3054.1994.900321.x

Jaouannet, M., Rodriguez, P. A., Thorpe, P., Lenoir, C. J. G., MacLeod, R., Escudero-Martinez, C., et al. (2014). Plant immunity in plant-aphid interactions. Front. Plant Sci. 5, 663. doi: 10.3389/fpls.2014.00663

Jutidamrongphan, W., Andersen, J. B., Mackinnon, G., Manners, J. M., Simpson, R. S., and Scott, K. J. (1991). Induction of $\beta$-1,3-glucanase in barley in response to infection by fungal pathogens. Mol. Plant-Microbe Interact. 4, 234-238. doi: 10.1094/MPMI-4-234

Koch, K. G., Donze-Reiner, T., Baird, L. M., Louis, J., Amundsen, K., Sarath, G., et al. (2018). Evaluation of greenbug and yellow sugarcane aphid feeding behavior on resistant and susceptible switchgrass cultivars. Bioenergy Res. 11, 480-490. doi: 10.1007/s12155-018-9914-3

Lawrenson, T., and Harwood, W. A. (2019). "Creating targeted gene knockouts in barley using CRISPR/Cas9," in Barley: Methods and protocols, Methods in molecular biology, vol. 1900 . Ed. W. A. Harwood (New York, USA: Humana Press), 217-232. doi: 10.1007/978-1-4939-8944-7_14

Leather, S. R., and Dixon, A. F. G. (1981). The effect of cereal growth stage and feeding site on the reproductive activity of the bird-cherry aphid, Rhopalosiphum padi. Ann. Appl. Biol. 97, 135-141. doi: 10.1111/j.1744-7348.1981.tb03006.x

Li, C.-D., Langridge, P., Lance, R. C. M., Xu, P., and Fincher, G. B. (1996). Seven members of the (1->3)- $\beta$-glucanase gene family in barley (Hordeum vulgare) are clustered on the long arm of chromosome 3 (3HL). Theor. Appl. Genet. 92, 791-796. doi: 10.1007/BF00221889

Li, Y.-F., Zhu, R., and Xu, P. (2005). Activation of the gene promoter of barley $\beta$ 1,3 -glucanase isoenzyme GIII is salicylic acid (SA)-dependent in transgenic rice plants. J. Plant Res. 118, 215-221. doi: 10.1007/s10265-005-0213-7

Luna, E., Pastor, V., Robert, J., Flors, V., Mauch-Mani, B., and Ton, J. (2011). Callose deposition: A multifaceted plant defense response. MPMI 24, 183-193. doi: 10.1094/MPMI-07-10-0149 
Mehrabi, S., Åhman, I., and Jonsson, L. M. V. (2016). The constitutive expression and induction of three $\beta$-1,3-glucanases by bird cherry-oat aphid in relation to aphid resistance in 15 barley breeding lines. Arthropod-Plant Interact. 10, 101111. doi: $10.1007 / \mathrm{s} 11829-016-9415-2$

Meihls, L. N., Handrick, V., Glauser, G., Barbier, H., Kaur, H., Haribal, M. M., et al. (2013). Natural variation in maize aphid resistance is associated with 2,4dihydroxy-7-methoxy-1,4-benzoxazin-3-one glucoside methyltransferase activity. Plant Cell 25, 2341-2355. doi: 10.1105/tpc.113.112409

Miller, G. L. (1959). Use of dinitrosalicylic acid reagent for determination of reducing sugar. Anal. Chem. 31, 426-428. doi: 10.1021/ac60147a030

Mornhinweg, D. W., Obert, D. E., and Carver, B. F. (2012). Registration of eight six-rowed feed barley germplasm lines resistant to both Russian wheat aphid and greenbug. J. Plant Reg. 6, 186-189. doi: 10.3198/jpr2011.09.0517crg

Mornhinweg, D. W., Hammon, R. W., and Obert, D. E. (2017). Registration of "Mesa" Russian wheat aphid-resistant winter feed barley. J. Plant Reg. 11, 8588. doi: 10.3198/jpr2016.09.0050crc

Mushtaq, M., Sakina, A., Wani, S. H., Shikari, A. B., Tripathi, P., Zaid, A., et al. (2019). Harnessing genome editing techniques to engineer disease resistance in plants. Front. Plant Sci. 10, 550. doi: 10.3389/fpls.2019.00550

Park, S.-J., Huang, Y., and Ayoubi, P. (2006). Identification of expression profiles of sorghum genes in response to greenbug phloem-feeding using CDNA subtraction and microarray analysis. Planta 223, 932-947. doi: 10.1007/s00425-005-0148-1

Pavan, S., Jacobsen, E., Visser, R. G. F., and Bai, Y. (2010). Loss of susceptibility as a novel breeding strategy for duarable and broad-spectrum resistance. Mol. Breed. 25, 1-12. doi: 10.1007/s11032-009-9323-6

Pirselova, B., and Matusikova, I. (2013). Callose: the plant cell wall polysaccharide with multiple biological functions. Acta Physiol. Plant 35, 635-644. doi: 10.1007/s11738-012-1103-y

Reddy, S. K., Weng, Y., Rudd, J. C., Akhunova, A., and Liu, S. (2013). Transcriptomics of induced defense responses to greenbug aphid feeding in near isogenic wheat lines. Plant Sci. 212, 26-36. doi: 10.1016/j.plantsci.2013.08.002

Rossi, M., Goggin, F. L., Milligan, S. B., Kaloshian, I., Ullman, D. E., and Williamson, V. M. (1998). The nematode resistance gene Mi of tomato confers resistance against the potato aphid. Proc. Natl. Acad. Sci. 95, 97509754. doi: 10.1073/pnas.95.17.9750

Roulin, S., Xu, P., Brown, A. H. D., and Fincher, G. B. (1997). Expression of specific (1->3)- $\beta$-glucanase genes in leaves of near-isogenic resistant and susceptible barley lines infected with the leaf scald fungus (Rhynchosporium secalis). Physiol. Mol. Phytopathol. 50, 245-261. doi: 10.1006/pmpp.1997.0084

Saheed, S. A., Cierlik, I., Larsson, K. A. E., Delp, G., Bradley, G., Jonsson, L. M. V., et al. (2009). Stronger induction of callose deposition in barley by Russian wheat aphid than bird cherry-oat aphid is not associated with differences in callose synthase or $\beta-1,3$-glucanase transcript abundance. Physiol. Plant 135, 150-161. doi: 10.1111/j.1399-3054.2008.01180.x

Samaha, H. (2017). Morphological and histological aspects of Solanum tuberosum plants infested by Macrosiphum euphorbiae aphids. J. Plant Dis. Prot. 124, 553562. doi: 10.1007/s41348-017-0115-7

Sedeek, K. E. M., Mahas, A., and Mahfouz, M. (2019). Plant genome engineering for targeted improvement of crop traits. Front. Plant Sci. 10, 114. doi: 10.3389/ fpls.2019.00114

Shan, Q., Wang, Y., Li, J., Zhang, Y., Chen, K., Liang, Z., et al. (2013). Targeted genome modification of crop plants using a CRISPR-Cas system. Nat. Biotechnol. 31, 686-688. doi: 10.1038/nbt.2650

Shoala, T., Edwards, M. G., Knight, M. R., and Gatehouse, A. M. R. (2018). OXI1 kinase plays a key role in resistance of Arabidopsis towards aphids (Myzus persicae). Transgenic Res. 27, 355-366. doi: 10.1007/s11248-018-0078-x

Smith, C. M. (1989). Resistance to insects - A fundamental approach Vol. 676 (New York: John Wiley \& Sons, Inc), ISBN.
Sun, Y., Guo, H., Yuan, E., and Ge, F. (2018a). Elevated $\mathrm{CO}_{2}$ increases R genedependent resistance of Medicago truncatula against the pea aphid by upregulating a heat shock gene. New Phytol. 217, 1696-1711. doi: 10.1111/nph.14892

Sun, M., Voorrips, R. E., Steenhuis-Broers, G., van't Westende, W., and Vosman, B. (2018b). Reduced phloem uptake of Myzus persicae on an aphid resistant pepper accession. BMC Plant Biol. 18, 138. doi: 10.1186/s12870-0181340-3

Tjallingii, W. F. (2006). Salivary secretions by aphids interacting with proteins of phloem wound responses. J. Exp. Bot. 57, 739-745. doi: 10.1093/jxb/erj088

Tolmay, V. L., Sydenham, S. L., Boshoff, W. H. P., Wentzel, B. S., Miles, C. W., and Booyse, M. (2015). Registration of five spring wheat lines resistant to Russian wheat aphid, stem rust (Ug99), leaf rust, and stripe rust. J. Plant Reg. 10, 80-86. doi: $10.3198 /$ jpr2015.03.0013 crg

Vandesompele, J., De Preter, K., Pattyn, F., Poppe, B., Van Roy, N., De Paepe, A., et al. (2002). Accurate normalization of real-time quantitative RT-PCR data by geometric averaging of multiple internal control genes. Genom. Biol. 3 (7). doi: 10.1186/gb-2002-3-7-research0034

Van Bel, A. J. E., and Will, T. (2016). Functional evaluation of proteins in watery and gel saliva of aphids. Front. Plant Sci. 7, 1840. doi: 10.3389/fpls.2016.01840

Van der Westhuizen, A. J., Qian, X.-M., and Botha, A.-M. (1998). $\beta$-1,3-glucanases in wheat and resistance to the Russian wheat aphid. Physiol. Plant. 103, 125131. doi: 10.1034/j.1399-3054.1998.1030115.x

Van der Westhuizen, A. J., Qian, X.-M., Wilding, M., and Botha, A.-M. (2002). Purification and immuno-cytochemical localization of a wheat $\beta$-1, 3-glucanase induced by Russian wheat aphid infestation. S. Afr. J. Sci. 98, 197-202.

Van Loon, L. C., and van Strien, E. A. (1999). The families of pathogenesis-related proteins, their activities, and comparative analysis of PR-1 type proteins. Physiol. Mol. Plant Pathol. 55, 85-97. doi: 10.1006/pmpp.1999.0213

Watson, A., Ghosh, S., Williams, M. J., Cuddy, W. S., Simmonds, J., Rey, M.-D., et al. (2018). Speed breeding is a powerful tool to accelerate crop research and breeding. Nat. Plants 4, 23-29. doi: 10.1038/s41477-017-0083-8

Weeks, D. P., Spalding, M. H., and Yang, B. (2015). Use of designer nucleases for targeted gene and genome editing in plants. Plant Biotechnol. J. 14, 483-495. doi: $10.1111 /$ pbi.12448

Will, T., and Vilcinskas, A. (2015). The structural sheath protein of aphids is required for phloem feeding. Insect Biochem. Mol. Biol. 57, 34-40. doi: 10.1016/ ibmb.2014.12.005

Will, T., Furch, A. C. U., and Zimmermann, M. R. (2013). How phloem-feeding insects face the challenge of phloem-located defenses. Front. Plant Sci. 4, 336. doi: $10.3389 /$ fpls.2013.00336

Xie, B., Wang, X., Zhu, M., Zhang, Z., and Hong, Z. (2011). CalS7 encodes a callose synthase responsible for callose deposition in the phloem. Plant J. 65, 1-14. doi: 10.1111/j.1365-313X.2010.04399.x

Zavaliev, R., Levy, A., Gera, A., and Epel, B. L. (2013). Subcellular dynamics and role of Arabidopsis $\beta$-1,3-glucanases in cell-to cell movement of tobamoviruses. MPMI 26, 1061-1030. doi: 10.1094/MPMI-03-13-0062

Conflict of Interest: The authors declare that the research was conducted in the absence of any commercial or financial relationships that could be construed as a potential conflict of interest.

Copyright $\odot 2020 \mathrm{Kim}$, Bengtsson, Olsson, Hot, Zhu and Åhman. This is an openaccess article distributed under the terms of the Creative Commons Attribution License (CC BY). The use, distribution or reproduction in other forums is permitted, provided the original author(s) and the copyright owner(s) are credited and that the original publication in this journal is cited, in accordance with accepted academic practice. No use, distribution or reproduction is permitted which does not comply with these terms. 